\title{
ADMINISTRATIVE ARREST IN THE ADMINISTRATIVE LIABILITY SYSTEM OF UKRAINE
}

\author{
Ivan Piskun ${ }^{1}$ \\ ${ }^{I}$ Associate Professor of Legal Support, Candidate of Law, Associate Professor, National University of \\ Defense of Ukraine, Kyiv, Ukraine, e-mail: ipiskun2016@gmail.com, ORCID: https://orcid.org/0000-0002- \\ 2401-7988
}

Abstract. The article is devoted to the study of the issue of administrative arrest in the system of administrative responsibility of Ukraine. A retrospective analysis of normative legal acts regulating administrative offenses in Ukraine is carried out. The purpose of the article is to determine the essence of correctional work as a type of administrative penalty, the procedure for its establishment and application on the basis of the analysis of the current legislation of Ukraine, generalization of the practice of its implementation, elaboration of theoretical provisions. The research methodology is general scientific methods, such as: historical-legal, system-structural and scientific generalization, which were used to clarify the essence of correctional work. The article provides proposals for regulatory support for the prosecution of persons with disabilities.

Keywords: administrative arrest, administrative responsibility, law, persons with disabilities.

JEL Classification: K15, K30, K40

Formulas: 0; fig.: 0; tabl.: 0; bibl.: 17

Introduction. The fundamental changes taking place in Ukraine towards the establishment of a social State governed by the rule of law also concern the reform of the Ukrainian legal system in general and of every branch of the law in particular. This also applies to administrative law, the concept of which has made the renewal of the legal institution of administrative responsibility one of the main directions of reform. An integral part of the reform of this institution is the reconsideration and scientific justification of the definition of administrative detention as an administrative penalty, introduced by article 24 of the Code of Administrative Offences (in the following CAO) and the procedure for its application. The transition in Ukraine from a relationship of the "State over man" type, in which the latter was given the place only of a managed object, to which authority and administrative influence from State bodies were directed to a "State for the Human Being", where the State has the primary duty "to affirm and ensure human rights and freedoms", and recognition of the State as the ultimate social value of the State (art. of the Constitution) considerably reduces the scope of the State's interference in human life through the use of various coercive measures and restrictions on his or her conduct.

Literature Review. The basic method of human-State relations in Ukraine today is persuasion, as a system of legal and non-legal measures, consisting in the application of educational measures, awareness-raising and promotional activities aimed at creating awareness among citizens of the need to comply strictly with the requirements of laws and other legal acts [2].

However, the widespread use of persuasion does not fully address the reasonable limits of its use as a means of coercion against persons who do not comply with legal regulations. This method is far from being sufficient to deal with this category of persons. That is why the State, while protecting the rights and freedoms of citizens 
and society as a whole, compels some of them, who are not amenable to persuasive measures, to respect the rule of law by applying various measures to them.

Aim. The aim is to determine the essence of correctional work as a type of administrative penalty, the procedure for its establishment and application on the basis of the analysis of the current legislation of Ukraine, generalization of the practice of its implementation, elaboration of theoretical provisions.

Methods. To clarify the essence of correctional work, preference was given to such general scientific methods as historical-legal, system-structural and scientific generalization.

Results. Traditionally, administrative coercion is regarded as a form of Statelegal coercion, a system of means of psychological or physical influence on the consciousness and behaviour of people, with a view to achieving clear fulfilment of the prescribed duties, development of society within the framework of the law and the rule of law. It is possible to specify the objectives of administrative enforcement measures - to ensure public order and security, to prevent and punish offences and to punish offenders [3].

It is well known that administrative penalties in the form of the last link in the system of administrative coercive measures are a means of implementing the administrative liability that arises for the commission of administrative offences by a person, an exhaustive list is given in Article 24 of the CAO. Administrative penalties are imposed for the purpose of educating a person who has committed an administrative offence to respect the laws of Ukraine and the rules of general residence; and also help to prevent the commission of administrative misconduct as the offender himself, such other persons.

According to the existing classification by the nature of the effect on a person, administrative detention refers to personal administrative sanctions having a corrective-educational effect. This penalty is imposed as the main penalty in the application procedure [4].

The administrative penalties in Art. 24 of the CAO are set out in the appropriate order. Differentiation in the severity of penalties is a systemic factor. Their core is the increase from minor (warning) to greater (confiscation) and severe penalties, such as punitive deduction of earnings and administrative detention. Administrative arrest is thus the most important criterion for the severity of penalties.

In the Art. 32 of the current CAO does not define the concept of administrative detention. It merely notes that administrative detention is imposed and applied in exceptional cases for certain types of administrative offences for up to 15 days. Administrative detention is ordered by a district, city district or district court (or by a judge).

It should be noted that, like any other administrative detention, administrative arrest is a measure of administrative coercion. Administrative coercion is a form of State coercion aimed at ensuring law and order and ensuring human and civil rights and freedoms. And it provides for the application of a set of administrative and legal measures to prevent offences [5]. 
It should be noted here that administrative arrest, as can be seen from the practice of its application and departmental administrative and legal acts of the Ministry of Internal Affairs of Ukraine, is no more than the detention of a person in conditions which prevent a citizen from moving freely and from living in a place of his choice [6]: In other words, it is a form of punishment whereby the freedom of movement and free choice of place of residence guaranteed by article 33 of the Constitution of Ukraine are temporarily restricted.

A special condition for the application of administrative arrest by the courts is that persons serving such penalties must be required to work. The Constitution prohibits the use of forced labour. However, according to the Basic Law, work or service performed by a person pursuant to a sentence or other court decision is not considered forced labour. Thus, the employment of persons held in administrative detention centres for administrative offences on the basis of court orders does not constitute forced labour. The purpose of employing persons arrested by the court on the basis of its decision is to educate such persons in employment, by developing their skills, habits and needs for work, and thus to be useful to society. This enables the person under administrative arrest to demonstrate by honest work and exemplary behaviour that he is on the path of correction and prevention of further unlawful acts.

The peculiarity of the above-mentioned type of penalty is the fact that administrative arrest is applied by the court only in exceptional cases for certain types of administrative misconduct. That is, such a measure can only be determined by a court order. Prior to the adoption and entry into force of the Code of Administrative Procedure, many scientists and practitioners of administrative law believed that cases of administrative offences would be dealt with by the administrative courts and thus, administrative penalties in the form of administrative arrest will also be imposed by the administrative court. However, the designation of an administrative court, as is known from the practice of these Western law enforcement agencies [8], is to settle disputes about the legality of individual administrative cases by public authorities. In modern democracies, the legal protection of an independent and authoritative body, the court, is of great importance for the protection of human rights in its relations with the authorities. The judicial mechanism for the protection of human rights makes it possible to eliminate the arbitrariness of the State by ensuring that the principle of its responsibility towards the individual is upheld. This mechanism is called "administrative justice". In most European countries, administrative justice is represented by specialized administrative courts [9]. The Code of Administrative Procedure of Ukraine, which entered into force on 1 September 2005, correctly states that the competence of administrative courts does not extend to public-law disputes concerning the imposition of administrative penalties [10]. Therefore, a decision in the form of an administrative penalty is taken by a local general district, city district or inter-district court. The removal of administrative offences from the jurisdiction of the administrative court is in fact appropriate for several reasons: first, the Administrative Court, as seen in the European system of administrative jurisdiction, does not have the right of prosecution; second, it is a human rights body whose main purpose is to protect human and civil rights and freedoms against unlawful actions by 
the executive and local authorities, and third, it is a body, who supervises the structures of public power and decides on the annulment of their unlawful decisions. In no case may a person be subjected to coercion by an administrative court [11]. The reaction of the administrative court to the violation of human and civil rights and freedoms is not only a right of the administrative court but also a direct duty [12].

Thus, administrative arrest is imposed only on individuals by the local general court, as defined in the Law of Ukraine "On the Judicial System and the Status of Judges" [13].

The fact that administrative detention is applied only in exceptional cases and for certain types of offences should be emphasized that the CAO contains few such articles providing for administrative detention for administrative offences. These are article 44. " Illicit production, acquisition, storage, transport or trans-shipment of narcotic drugs or psychotropic substances without the purpose of marketing them in small quantities"; 51. "Misappropriation of property"; 173 "Petty hooliganism"; 1732 "Commission of domestic violence, gender-based violence, failure to comply with the time-limit prohibition or failure to communicate the place of temporary stay"; 178. "Drinking of beer, alcoholic beverages, soft beverages in illegal or intoxicated public places»; 185. "Wilful disobedience to a lawful order or demand by a police officer, a member of a public security group for the protection of public order and the State border, a member of the armed forces"; 185-1. "Violation of the procedure for organizing and holding assemblies, meetings, street processions and demonstrations"; 185-3 "Contempt of court or the Constitutional Court of Ukraine"; 185-10. " Wilful disobedience to a lawful order or demand from a member of the Ukrainian State Border Service or a member of a public security group to protect public order and the State border"; 204-1. "illegal crossing or attempted illegal crossing of the state border of Ukraine". A comparative analysis of the text of the CAO of Ukraine, which was in force until 1991, that is, before Ukraine became independent, and in the current period leads to the conclusion that, the application of this type of penalty as administrative detention has been considerably expanded.

To sum up, we can conclude that the definition of administrative arrest is the detention of a person who has committed an administrative offence, in solitary confinement with compulsory labour, and for a period of up to 15 days, the courts apply only in exceptional cases for certain types of administrative offences defined in the CAO.

Administrative detention differs from what is called arrest under Ukrainian and international law, is used to ensure legality and is governed by the norms of other branches of law. In addition, the law includes both the seizure of a person and the seizure of assets, property and even a ship or aircraft. The subjects of administrative or criminal proceedings for administrative arrest and arrest, as provided for in the Criminal Code, are also different. Under criminal law, persons under the age of 16 may not be arrested, and administrative law prohibits the imposition of administrative detention on persons under the age of 18. Such disagreements, in our view, stem from the fact that administrative arrest is a lesser penalty for other custodial sentences. In administrative law, administrative detention is the most severe form of administrative 
punishment. Under criminal law, detention is also not applied to pregnant women or to women with children under the age of seven. The Art. 32 of the Ukrainian CAO also prohibits the imposition of such penalties on pregnant women and women with children. However, the age of administrative detention may be considerably higher for children up to the age of 12 .

The Code of Administrative Offences notes that administrative detention does not apply to category I and II disabled persons. This is correct, since the regime for the detention of such persons provides for their use in corrective labour. Persons with disabilities may not work physically and are in fact not subject to the regime for persons under administrative arrest. However, it was not clear why persons with limited legal capacity, or third-party disabled persons, were subject to administrative arrest. Under the Act "On the foundations of social protection for disabled persons in Ukraine", a disabled person is a person with a permanent impairment of bodily functions caused by illness, injury or birth defects, resulting in the restriction of vital activity and the need for social assistance and protection, and the Article 3 of this Act defines disability as a measure of loss of health by means of an expert examination by the medical and social assessment bodies of the Ministry of Health [14].

Discussion. The procedure for establishing disability groups is provided in the Instruction of the Ministry of Health, approved by the order 183 of the central executive authority from 7 April 2004. The basis for the determination of the third disability group is a persistent, moderate impairment due to illness, injury or birth defects, which have resulted in moderately restricted activities, including working capacity, in need of social assistance and social protection. The criteria for determining group III disability are to limit one or more categories of activity to a moderate degree: limitation of self-service (degree I); limitation of the ability to move independently (degree I); limitations of ability to learn (degree I); limitations of ability to work (degree I); limitations of ability to orient (degree I); limitations of ability to communicate (degree I); limitations of ability to control one's behavior (degree I) [16].

Moderately restricted activity is the partial loss of opportunities for meaningful work (loss of occupation, significant loss of qualification or decline in work; significant difficulty in acquiring a profession or in finding a job): significant decrease (by more than 25 per cent) in the volume of work; Loss of a profession or significant loss of qualification; significant difficulty in acquiring a profession or in finding employment with persons who have never worked or have no occupation before. And even the Law of Ukraine of May 18, 2004 № 1727 - IU "On state social assistance to persons who do not have the right to a pension and the disabled", disabled people of the third group, who are lonely and according to the conclusion of the medical advisory commission need constant third-party care, are assigned social assistance [17].

Conclusions. It was clear that such persons could not be kept in isolation and could not be involved in physical work. It is therefore proposed that article 32 of the CAO should be supplemented, given that persons with disabilities in the third category are also not subject to administrative arrest, especially since the practice of 
imposing this type of punishment is precisely by not applying it to persons with disabilities in the third category.

\section{References:}

1. The Constitution of Ukraine. Press of Ukraine. 1977. 80 p.

2. Law of Ukraine "On Amendments to the Constitution of Ukraine" of December 8, 2004 № 2222 - IU // Bulletin of the Verkhovna Rada of Ukraine. 2005. № 2. pp. 44.

3. Convention on International Civil Aviation 1944. Official Gazette of Ukraine. 2004. № 40. pp. 2667.

5. Code of Labor Laws of Ukraine. Bulletin of the Verkhovna Rada of Ukraine. 1971. № 50 (appendix). pp. 357.

7. Fundamentals of the legislation of the USSR and the union republics on administrative offenses. // Information of the Supreme Soviet of the USSR. 1980. № 44. pp. 909.

8. Code of Administrative Procedure of Ukraine. Information of the Verkhovna Rada of Ukraine. 2005. № 37. pp. 446.

9. Criminal Code of Ukraine. December 28, 1960. Information of the Verkhovna Rada of Ukraine. - 1960. №

2. pp. 14.

10. Criminal Code of Ukraine. Information of the Verkhovna Rada of Ukraine. 2001. № 25-26. pp. 131.

11. Administrative Code of the Ukrainian Soviet Socialist Republic. Collection of Legalizations and Orders of the Workers 'and Peasants' Government of Ukraine for 1927. Official publication of the People's Commissariat of Justice. December 31, 1927, parts 63-65. Narlit Department. - pp.1218-1229

12. Administrative Code of the USSR. K. 1934.

13. Budget Code of Ukraine. Voice of Ukraine. 2001. July 24.

14. Water Code of Ukraine // Bulletin of the Verkhovna Rada of Ukraine. 1995. №24. Article 189.

15. Commercial Procedural Code of Ukraine (as amended by the Law of Ukraine of June 21, 2001. Voice of Ukraine. 2001. June 5.

16. Housing Code of Ukraine. Bulletin of the Verkhovna Rada of Ukraine. 1983. №28. Article 574.

17. Criminal Procedure Code of Ukraine. K. 2001. 